\title{
TRAUMATIC SHOCK. XII. HEMODYNAMIC EFFECTS OF ALTERA- TIONS OF BLOOD VISCOSITY IN NORMAL DOGS AND IN DOGS IN SHOCK ${ }^{1}$
}

\author{
By ARNOLD M. SELIGMAN, HOWARD A. FRANK, AND JACOB FINE \\ (From the Surgical Research Department, Beth Israel Hospital, and the Department of Surgery, \\ Harvard Medical School, Boston)
}

(Received for publication January 16, 1945)

Striking differences have been noted between dogs in hemorrhagic and in tourniquet shock (1). In both types, there is a reduction in blood volume, but the hematocrit and blood viscosity, which remain substantially unchanged in hemorrhagic shock, increase in tourniquet shock. At a blood pressure level of 80 to $100 \mathrm{~mm}$. $\mathrm{Hg}$, the dog in hemorrhagic shock is only mildly depressed and is still responsive to ordinary stimuli ; whereas, in tourniquet shock he is already severely depressed, unresponsive to strong stimulation, much more sensitive to further slight blood loss, and is in a state of rapid deterioration. When the pressure falls below 70 to $80 \mathrm{~mm}$. $\mathrm{Hg}$ in tourniquet shock, the collapse is precipitous; whereas, the unanesthetized dog in hemorrhagic shock can tolerate a blood pressure of $50 \mathrm{~mm}$. $\mathrm{Hg}$ for many hours. These differences have been explained on the basis of a toxin from devitalized tissue $(2,3)$ or bacteria (4) in the tourniqueted extremity. The successful treatment of tourniquet shock in the unanesthetized dog by plasma infusion alone (1) constitutes evidence against the "toxin" hypothesis.

Since the increase in blood viscosity in tourniquet shock is one of the outspoken differences between tourniquet and hemorrhagic shock, the effect of increased blood viscosity on blood flow in the intact and shocked animal was investigated to see how far it might explain the sharp disparity between these two types of shock.

\section{METHOD}

According to Poiseuille's equation

(1) $\quad$ Flow $=\frac{\text { Pressure }}{\text { Viscosity } \times \text { Resistance }} \times$ Constant

1 The work described in this paper was done under a contract, recommended by the Committee on Medical Research, between the Office of Scientific Research and Development and Harvard University.
Although this formula applies rigorously only to flow of homogeneous fluids in rigid tubes, it has been shown (5) that the formula can be used to relate viscosity to blood flow through the perfused isolated hind limb of the dog. In the intact animal, therefore, blood flow (or cardiac output) may be considered to be determined by the mean arterial pressure, a constant, and the total peripheral resistance $(T P R)$. The $T P R$ is the product of blood viscosity $(\eta)$ and the peripheral resistance $(R)$ which is dependent upon the number, length, and diameter of the blood vessels. The data obtained in the following experiments represent an effort to quantitate all the factors in Poiseuille's equation. The cardiac output, the mean arterial pressure and the blood viscosity $(\eta)$ were measured, while the constant and peripheral resistance $(R)$ were determined indirectly. With such data the effect of blood viscosity on total blood flow can be evaluated.

\section{(a) Determination of peripheral resistance $(R)$}

Total peripheral resistance $(T P R)$ in the animal as a whole is ordinarily calculated from the formula $T P R=$ Pressure

Cardiac output. For our purposes; this is inadequate since it does not take into account the blood viscosity which, if altered, affects the $T P R .^{2}$

If it is assumed that the peripheral resistance $(R)$ per $\mathrm{kgm}$. of normal dog is unity, Poiseuille's equation then changes for the normal dog from

$$
K=\frac{O \times \eta \times R}{P}
$$

to

$$
K=\frac{O \times \eta}{P}
$$

2 Some authors have preferred to express the unit of peripheral resistance (6) $(P R U)$ as $\frac{1 \mathrm{~mm} \text {. } \mathrm{Hg}}{1 \mathrm{ml} \text {. per minute }}$, and others prefer to convert to an absolute unit of peripheral resistance $(A U)$ (7) by multiplying the above ratio by $\frac{1330.60}{\mathrm{~cm}^{2}}$ and consider 1 absolute unit as $\frac{1 \text { dyne second }}{\mathrm{cm}^{6}}$. We agree with Green et al. (6) that the latter mode of expression is not readily appreciated and does not increase the accuracy. Furthermore, neither expression serves the purpose of this investigation because the influence of blood viscosity upon $T P R$ is not reflected in these formulas. 
where

$K=$ a constant

$O=$ cardiac output in $\mathrm{ml}$. per minute per $\mathrm{kgm}$. of dog

$\eta=$ apparent relative viscosity of blood

$P=$ mean arterial pressure in $\mathrm{mm}$. $\mathrm{Hg}$

$\boldsymbol{R}=$ peripheral resistance per $\mathrm{kgm}$. of $\mathrm{dog}$, assumed to be unity in the normal dog

The validity of the assumption that $R=1$ can be tested by determining the constancy of $K$ in normal dogs. This was done in 23 unanesthetized normal dogs (Table I), and the average $K$ was determined to be 8.1. The ratio of $K$ in any given experiment to the average $K$ of 8.1 showed in normal dogs an extreme variation of 0.5 to 1.8 , but in 70 per cent of these animals the ratio had a range of 0.8 to 1.2. Thus, the range of $R$ may be said to be sufficiently narrow to justify the assumption that $R=1$. The average $K$ was used in subsequent determinations of $R$ per $\mathrm{kgm}$. of $\mathrm{dog}$ as follows :

$$
R=\frac{P \times 8.1}{O \times \eta}
$$

$R$, derived in this way, is an expression of the ratio of the peripheral resistance (apart from viscosity) of the test animal to that of the normal animal and, therefore, has no absolute unit dimension.

Because the cardiac output varies directly and the $T P R$ varies inversely with the size of the animal, it was found convenient to express both the cardiac output and peripheral resistance $(R)$ on a unit weight basis. A weight basis rather than a surface area basis was preferred because the calculation of the former was simpler and more easily appreciated.

\section{(b) Determination of viscosity}

Since the viscosity of blood relative to water varies with the condition and type of apparatus used, the term "apparent" relative viscosity has been used (5) in order to take into account the specific conditions under which relative viscosity was determined. While the flow of blood through the isolated hind limb of the dog differs from that through a glass viscometer, especially in high hematocrit ranges, a sufficiently constant relationship is obtained through the physiologic range of perfusion pressures and, therefore, the glass viscometer measurement can be used as a valid index of changes in intravascular viscosity (5). The higher the velocity flow at which relative viscosity was measured in a glass tube, the lower the apparent relative viscosity was found to be and the nearer this approximated the findings in the perfused hind limb. But; the discrepancy between the measurements of apparent relative viscosity in a viscometer and in the hind limb increases as hematocrit increases. At a hematocrit of 50 per cent the apparent relative viscosity of blood flowing through the limb was found to be half that of the same blood flowing through a high velocity viscometer, while at a hematocrit of 70 per cent the ratio was 1 to 3. At very low pressures and low velocity flow, the apparent relative viscosity of blood rises (5). Hence the reading of apparent relative viscosity given by the high velocity viscometer will not reflect the same relationship to the viscosity of circulating blood in the shocked dog as it does to that of the normal dog. Furthermore perfusion of an innervated hind limb of the dog has shown (8) that vasoconstriction can markedly increase the apparent relative viscosity. The very low blood pressure, very low velocity flow, and increase in vasoconstriction of advanced shock increase the apparent viscosity of the circulating blood toward that obtained with the high velocity viscometer.

Hence, the calculation of the peripheral resistance $(R)$ from Poiseuille's equation, under conditions of reduced blood pressure and vasoconstriction, at best, is likely to be only of approximate accuracy because of the unpredictable deviation of the apparent viscosity of the blood in the blood vessels from that in the viscometer. Since vis$\operatorname{cosity}(\eta)$ is indeterminately higher at very low perfusion pressures, $R$ cannot be determined accurately at very low blood pressure levels. Nevertheless, the trend of $\eta$ and $R$ can be assessed individually in shock, so that it is fair and useful to separate these two components of the total peripheral resistance $(T P R)$ for the purpose of determining the effects of their variations.

\section{(c) General experimental procedure}

Healthy mongrel dogs varying in weight from 5 to 25 $\mathrm{kgm}$. were given morphine sulphate $(2$ to $3 \mathrm{mgm}$. per kgm.) intramuscularly $1 / 2$ to 1 hour before the experiment. No further morphine was given, and no general anesthesia was administered. Exposure of vessels and tracheotomy were done under local procaine anesthesia without aseptic precautions. Sulfanilamide powder was placed in the wounds during the experimental period and at the time of closure. At least 1 to 2 hours were allowed to elapse between completion of these preliminary surgical procedures and the first control readings of cardiac output. The animals remained on the table throughout the experimental period. The blood pressure was observed continuously by means of a mercury manometer attached to a cannula (containing heparin and saline) which was placed in the femoral artery. Blood samples for hematocrit, viscosity and arterial oxygen content determinations were taken by needle puncture of the femoral (rarely the carotid) artery. Samples of mixed venous blood were obtained from the right auricle by means of a straight glass tube passed through the left external jugular vein at the moment of sampling, or through a ureteral catheter passed in the same manner but allowed to remain in situ throughout the experiment. The catheter was filled with dilute heparin between determinations. Venous pressures were measured with reference to the level of the auricle, as estimated on the chest wall by a saline manometer attached to the auricular catheter or to a needle in a femoral vein. Blood oxygen determinations in duplicate were made by the manometric method of Van Slyke and Neill (9). Oxygen consumption was measured during a 10-minute period of oxygen inhalation from a spirometer. The cardiac output was determined by the 
direct Fick principle. Cardiac output is tabulated in terms of body weight (liters per minute per $10 \mathrm{kgm}$.), or as "cardiac index" in terms of surface area (liters per minute per square meter). The surface area was calculated from the weight formula of Benedict (10). Hematocrit samples were kept from clotting by the addition of potassium and ammonium oxalate crystals, and the hematocrit was determined by centrifugation at 2,000 r.p.m. for 30 minutes in Wintrobe tubes. Blood for the measurement of blood viscosity was kept from clotting by the addition of heparin. The viscosity of blood was determined by the high velocity method in an Ostwald tube $10.5 \mathrm{~cm}$. in length and about $0.5 \mathrm{~mm}$. in diameter under a pressure of $38 \mathrm{~cm}$. of water in a constant temperature bath at $37.5 \mathrm{C.}$ The period of time for passage of $5 \mathrm{ml}$. was referred to that for water (20 seconds).

Blood taken from another dog was given to replace the volume taken at each sampling.

The term "exchange" is used throughout this report to indicate a withdrawal of blood from an artery or vein, followed immediately or accompanied by a return of the

3 Whittaker and Winton (5) used a tube $30 \mathrm{~cm}$. in length, $0.93 \mathrm{~mm}$. in diameter, through which blood was driven at pressures varying from 30 to $120 \mathrm{~mm}$. $\mathrm{Hg}$. The velocity flow in our apparatus was comparable to theirs. same volume of blood into the opposite corresponding vein. Exchanges were done in order to alter the hematocrit without change in blood volume. In control experiments, the withdrawn blood was replaced immediately by the animal's own blood previously removed or by blood from a normal compatible donor dog. To increase hematocrit, the withdrawn blood was replaced by an equal volume of compatible red cells concentrated by centrifugation and freed of plasma. In some instances, these cells were washed by resuspension once or twice in 0.85 per cent saline solution. A reduction in hematocrit was effected by exchanges in which the withdrawn blood was replaced by normal dog plasma or by a 5 per cent solution of crystallized bovine albumin 4 in 0.85 per cent saline solution.

\section{RESULTS}

\section{Cardiac output in normal dogs}

In a series of 23 normal dogs ranging in weight from 5 to $25 \mathrm{kgm}$., the cardiac output per $10 \mathrm{kgm}$. of dog varied from 1.16 to 2.91 liters per minute, and the cardiac index

4 Provided through the courtesy of Prof. E. J. Cohn, Department of Physical Chemistry, Harvard Medical School.

TABLE I

Data from normal dogs used in calculating the constant $(K)^{*}$

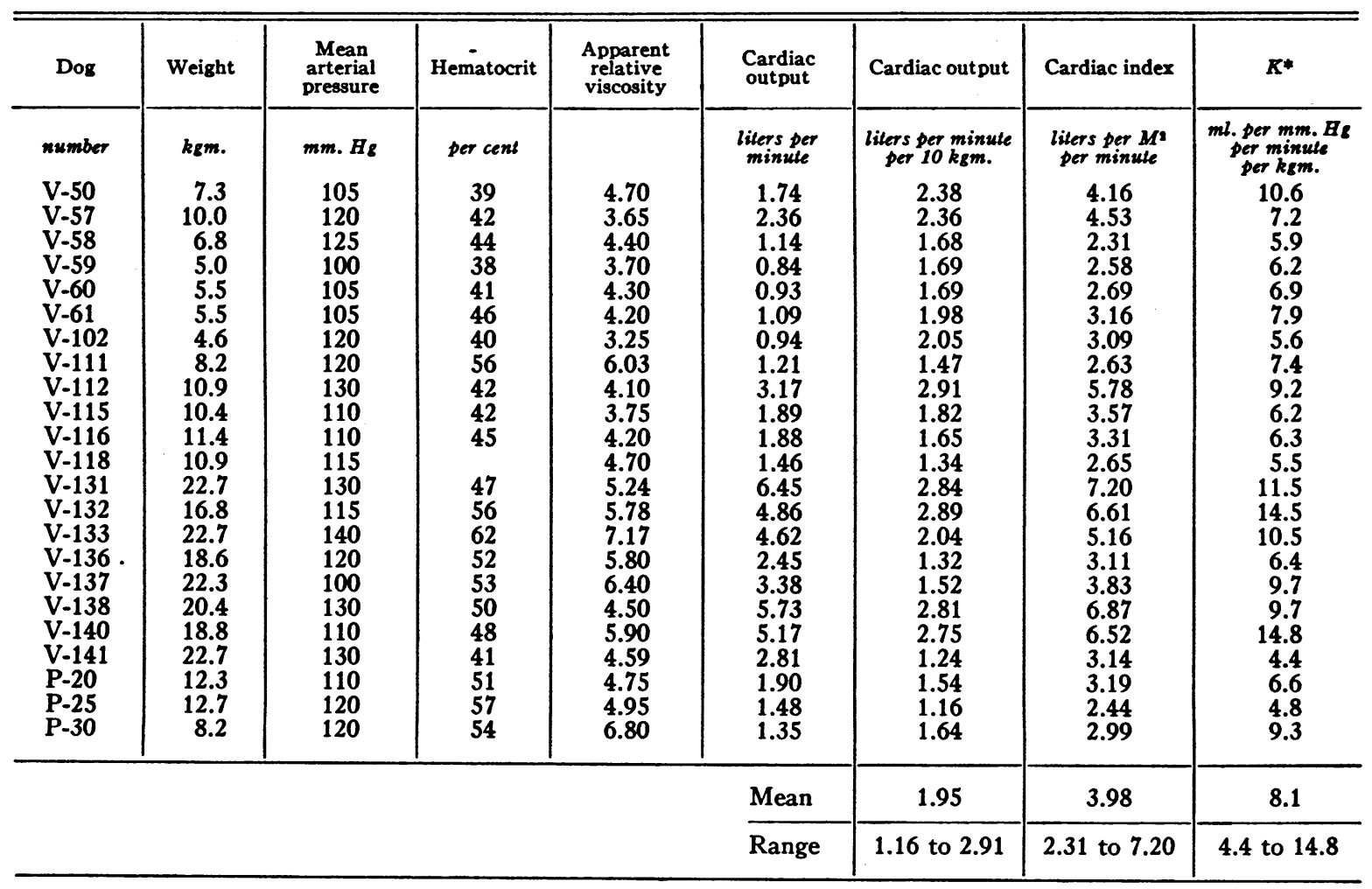

$* K=\frac{\text { cardiac output in ml. per minute } \times \text { apparent relative viscosity of blood }}{\text { mean arterial pressure } \times \text { weight of dogs in kgm. }} \times R$, where $R$ (peripheral resistance apart from blood viscosity) is assumed to be unity for the normal dog per kgm. 
varied from 2.3 to 7.2 liters per minute per square meter of body surface (Table I). The mean cardiac index in our series was higher, and the cardiac indices varied more than in a series of normal anesthetized dogs reported by Wiggers (7). He reported an average cardiac index of 2.75 to 2.93 for dogs varying in weight from 10 to $30 \mathrm{kgm}$. If the dogs shown in Table I are grouped as follows:

\begin{tabular}{l|c|c|c}
\hline \hline & $\begin{array}{c}\text { Mean } \\
\text { cardiac } \\
\text { index }\end{array}$ & $\begin{array}{c}\text { Mean } \\
\text { cardiac } \\
\text { output }\end{array}$ & $\begin{array}{c}\text { Mean } \\
K\end{array}$ \\
\hline & $\begin{array}{c}\text { liters per } \\
\text { minute per } \\
\text { square } \\
\text { meter }\end{array}$ & $\begin{array}{c}\text { liters per } \\
\text { minute per } \\
10 \mathrm{kgm} .\end{array}$ & $\begin{array}{c}\text { ml. per } \\
\text { mikute per } \\
\text { mm. } \\
\text { per } \mathrm{kgm} .\end{array}$ \\
Small dogs (4 to $8 \mathrm{kgm})$. & 3.00 & 1.91 & 7.2 \\
Medium dogs (8 to $15 \mathrm{kgm})$. & 3.45 & 1.76 & 6.9 \\
Large dogs (15 to $25 \mathrm{kgm})$. & 5.30 & 2.17 & 10.2 \\
\hline
\end{tabular}

it is found that the cardiac indices as measured in our experiments are not only larger and less constant than those found by Wiggers, but also that they are larger in larger dogs. Wigger's average cardiac index is not related to dog size. We attribute the lower figure found by him to his use of barbiturate anesthesia which probably results in a measurement of basal cardiac output. Greater constancy appears in our data when cardiac output is expressed on a weight basis than on a surface area basis.
Utilizing equation 2, the constant $K$ was determined in each case per $\mathrm{kgm}$. of dog and found to vary from 4.4 to 14.8 with a mean of $8.1 \mathrm{ml}$. per minute per $\mathrm{mm}$. $\mathrm{Hg}$ per $\mathrm{kgm}$. (Table I). This value, 8.1, was used in subsequent calculations of the peripheral resistance $(R)$ of dogs with experimentally altered hematocrit and of dogs in shock ( $R$ is expressed as a ratio on a unit weight basis). The mean value of $K$ (Table $\mathrm{I}$ ) was used regardless of the size of the animal since we were not concerned with absolute values of $R$, but only with fluctuations of $R$ in any given animal.

\section{Repeated cardiac outputs in normal dogs}

Considerable variation in cardiac output was noted in mildly morphinized dogs from time to time during a single experimental period (Table II). The dogs have been grouped so as to show those whose cardiac outputs fluctuated within normal limits, those that showed an abnormal decline, and those that started with abnormally low outputs and fluctuated in and out of the normal range. The fluctuation of cardiac output in our unanes-

TABLE II

Initial and subsequent determinations of cardiac output in dogs during the control period

\begin{tabular}{|c|c|c|c|c|c|c|c|c|c|c|c|}
\hline \multirow[t]{2}{*}{. $\quad \cdot$} & \multirow{2}{*}{ Dog } & \multirow{2}{*}{ Weight } & \multirow{2}{*}{ Time* } & \multirow{2}{*}{$\begin{array}{l}\text { Initial } \\
\text { cardiac } \\
\text { output }\end{array}$} & \multicolumn{7}{|c|}{ Subsequent cardiac outputs } \\
\hline & & & & & $\begin{array}{l}\text { O to } 1 \\
\text { hour }\end{array}$ & $\begin{array}{l}\text { to } 1 \\
\text { hour }\end{array}$ & $\begin{array}{l}1 \text { to } 2 \\
\text { hours }\end{array}$ & $\begin{array}{l}2 \text { to } 3 \\
\text { hours }\end{array}$ & $\begin{array}{l}3 \text { to } 4 \\
\text { hours }\end{array}$ & $\begin{array}{l}4 \text { to } 5 \\
\text { hours }\end{array}$ & $\begin{array}{l}5 \text { to } 6 \\
\text { hours }\end{array}$ \\
\hline $\begin{array}{l}\text { Dogs whose cardiac output re- } \\
\text { mained within normal limits } \\
\text { (see Table I) }\end{array}$ & $\begin{array}{l}\text { number } \\
\text { V-119 } \\
\text { V-121 } \\
\text { V-122 } \\
\text { V-123 } \\
\text { V-124 } \\
\text { V-125 } \\
\text { V-137 } \\
\text { V-131 } \\
\text { V-132 } \\
\text { V-133 } \\
V-136 \ddagger\end{array}$ & $\begin{array}{l}\text { kgm. } \\
12.7 \\
14.5 \\
15.9 \\
14.3 \\
12.7 \\
12.5 \\
22.3 \\
22.7 \\
16.8 \\
22.7 \\
18.6\end{array}$ & $\begin{array}{r}\text { minutes } \\
120 \\
30 \\
40 \\
40 \\
80 \\
40 \\
150 \\
90 \\
60 \\
105 \\
60\end{array}$ & $\begin{array}{c}\text { liters per } \\
\text { minute per } \\
10 \mathrm{kgm} \text {. } \\
1.95 \\
1.60 \\
1.43 \\
2.70 \\
2.99 \\
2.71 \\
1.51 \\
2.71 \\
2.90 \\
1.53 \\
1.13\end{array}$ & $\begin{array}{l}1.10 \\
2.34 \\
3.85 \\
1.54 \\
2.96 \\
1.23 \\
2.22 \\
2.58 \\
2.04\end{array}$ & 1.86 & $\begin{array}{l}\text { lers per } \\
1.27 \\
2.00 \\
1.54 \\
1.64 \\
\\
3.54 \\
0.67 \\
1.34 \\
1.32\end{array}$ & 1.76 & $10 \mathrm{~kg}$ & $\begin{array}{l}1.90 \\
1.52\end{array}$ & \\
\hline $\begin{array}{l}\text { Dogs whose cardiac output de- } \\
\text { clined from normal initial } \\
\text { values }\end{array}$ & $\begin{array}{l}V-127 t \\
V-128 t \\
V-118 t\end{array}$ & $\begin{array}{l}11.5 \\
10.2 \\
10.9\end{array}$ & $\begin{array}{l}50 \\
60 \\
45\end{array}$ & $\begin{array}{l}1.78 \\
3.50 \\
1.34\end{array}$ & $\begin{array}{l}1.12 \\
4.95\end{array}$ & 1.12 & 0.79 & $\begin{array}{l}0.62 \\
0.65\end{array}$ & 0.64 & $\begin{array}{l}0.62 \\
0.79 \\
\end{array}$ & 0.84 \\
\hline $\begin{array}{l}\text { Dogs whose cardiac outputs } \\
\text { were abnormally low from } \\
\text { the start or fluctuated in } \\
\text { and out of the normal range }\end{array}$ & $\begin{array}{l}\text { V-117t } \\
\text { V-129t } \\
\text { V-134t } \\
\text { V-130t } \\
V-120 t\end{array}$ & $\begin{array}{l}11.8 \\
14.6 \\
19.5 \\
21.0 \\
21.8\end{array}$ & $\begin{array}{r}20 \\
185 \\
55 \\
70 \\
50\end{array}$ & $\begin{array}{l}0.94 \\
0.84 \\
1.08 \\
0.56 \\
1.14\end{array}$ & $\begin{array}{l}0.60 \\
2.30\end{array}$ & 0.52 & $\begin{array}{l}0.57 \\
0.83 \\
1.16\end{array}$ & 0.91 & $\begin{array}{l}1.96 \\
0.98\end{array}$ & 0.93 & 0.96 \\
\hline
\end{tabular}

* Interval between completion of surgical procedures and first measurement of cardiac output.

+ Interval between completion of surgical procedures and first measurement of cardiac output. mination of cardiac output.

¥ Auricular blood sample obtained through ureteral catheter passed via the external jugular vein at start of experiment and allowed to remain thereafter. 
TABLE III

Effect on cardiac output* of hemorrhage from femoral artery followed by transfusion of same volume of blood into femoral vein

\begin{tabular}{|c|c|c|c|c|c|c|c|c|c|c|c|c|c|c|}
\hline \multirow{5}{*}{$\begin{array}{c}\text { Dog } \\
\text { number } \\
\text { V-111 }\end{array}$} & \multirow{5}{*}{\begin{tabular}{|c|} 
Weight \\
kgm. \\
8.2
\end{tabular}} & \multirow{2}{*}{\multicolumn{3}{|c|}{$\begin{array}{l}\text { Cardiac output before } \\
\text { arterio-venous exchange }\end{array}$}} & \multicolumn{6}{|c|}{ Exchange period } & \multirow{2}{*}{\multicolumn{4}{|c|}{$\begin{array}{l}\text { Cardiac output after } \\
\text { arterio-venous exchange }\end{array}$}} \\
\hline & & & & & \multirow{2}{*}{$\begin{array}{l}\text { Total } \\
\text { volume of } \\
\text { exchange }\end{array}$} & \multirow{2}{*}{$\begin{array}{c}\text { Number } \\
\text { of } \\
\text { portions } \\
\text { exchanged }\end{array}$} & \multicolumn{3}{|c|}{ Blood pressure } & \multirow{2}{*}{$\begin{array}{c}\text { Hemato- } \\
\text { crit } \\
\text { change }\end{array}$} & & & & \\
\hline & & $\begin{array}{l}2 \text { to } 3 \\
\text { hours }\end{array}$ & $\begin{array}{l}1 \text { to } 2 \\
\text { hours }\end{array}$ & $\begin{array}{l}0 \text { to } 1 \\
\text { hour }\end{array}$ & & & Before & During & After & & $\begin{array}{l}\text { O to } 1 \\
\text { hour }\end{array}$ & $\begin{array}{l}1 \text { to } 2 \\
\text { hours }\end{array}$ & $\begin{array}{l}2 \text { to } 3 \\
\text { hours }\end{array}$ & $\begin{array}{l}3 \text { to } 4 \\
\text { hours }\end{array}$ \\
\hline & & \multicolumn{3}{|c|}{$\begin{array}{l}\text { liters per minute } \\
\text { per } 10 \mathrm{kgm} .\end{array}$} & $\begin{array}{c}\text { ml. per } \\
\text { kgm. }\end{array}$ & & \multicolumn{3}{|c|}{ mm. $H_{8}$} & per cent & \multicolumn{4}{|c|}{ liters per minute per $10 \mathrm{kgm}}$. \\
\hline & & & & $\begin{array}{l}1.48 \\
1.72 \\
0.77\end{array}$ & $\begin{array}{l}14.5 \\
18.0 \\
24.5\end{array}$ & $\begin{array}{l}1 \\
1 \\
1\end{array}$ & $\begin{array}{l}130 \\
140 \\
135\end{array}$ & $\begin{array}{r}120 \\
110 \\
40\end{array}$ & $\begin{array}{l}150 \\
150 \\
150\end{array}$ & $\begin{array}{l}-1 \\
+3 \\
-2\end{array}$ & $\begin{array}{l}1.72 \\
0.77 \\
0.69\end{array}$ & & & \\
\hline V-114 & 13.6 & & & 0.85 & 23.0 & 1 & 130 & 60 & 120 & -2 & 0.68 & 1.03 & & \\
\hline V-115 & 10.4 & & & $\begin{array}{l}1.82 \\
1.14\end{array}$ & $\begin{array}{l}31.2 \\
20.6\end{array}$ & $\begin{array}{l}1 \\
1\end{array}$ & $\begin{array}{l}110 \\
100\end{array}$ & $\begin{array}{l}50 \\
50\end{array}$ & $\begin{array}{l}105 \\
105\end{array}$ & $\begin{array}{r}0 \\
-7\end{array}$ & $\begin{array}{l}1.14 \\
1.02\end{array}$ & 0.67 & & \\
\hline V-116 & 11.4 & & & 1.65 & 43.8 & 1 & 110 & 40 & 110 & -4 & 0.94 & 1.01 & & 0.85 \\
\hline V-121 & 14.5 & & & $\begin{array}{l}1.10 \\
1.10\end{array}$ & $\begin{array}{l}35.0 \\
21.4\end{array}$ & $\begin{array}{l}1 \\
1\end{array}$ & $\begin{array}{l}120 \\
120\end{array}$ & $\begin{array}{l}65 \\
35\end{array}$ & $\begin{array}{l}120 \\
120\end{array}$ & & $\begin{array}{l}1.10 \\
0.78\end{array}$ & & 1.16 & \\
\hline V-122 & 16.0 & & 2.34 & 1.86 & 28.0 & 1 & 120 & 50 & 120 & & 1.16 & 0.88 & & 1.04 \\
\hline V-123 & 14.3 & 2.70 & 3.85 & 2.00 & 41.0 & 9 & 120 & 130 & 120 & & 1.87 & 1.38 & 1.16 & \\
\hline V-124 & 12.7 & 1.54 & & 1.54 & 42.5 & 9 & 110 & 110 & 110 & & 1.19 & 1.20 & 1.01 & \\
\hline
\end{tabular}

* One-half hour was allowed to elapse between completion of exchange and subsequent cardiac output determination ${ }^{\circ}$

† Dogs' own heparinized blood was returned.

TABLE IV

Effect on cardiac output of hemorrhage from femoral vein with simultaneous transfusion of same volume of blood into the other femoral vein, without change in blood pressure

\begin{tabular}{|c|c|c|c|c|c|c|c|c|c|}
\hline \multirow{2}{*}{ Dog } & \multirow{2}{*}{ Weight } & \multicolumn{3}{|c|}{ Cardiac output before exchange } & \multicolumn{2}{|c|}{ Exchange period } & \multicolumn{3}{|c|}{ Cardiac output after exchange } \\
\hline & & $\begin{array}{l}2 \text { to } 3 \\
\text { hours }\end{array}$ & $\begin{array}{l}1 \text { to } 2 \\
\text { hours }\end{array}$ & $\begin{array}{l}0 \text { to } 1 \\
\text { hour }\end{array}$ & $\begin{array}{l}\text { Volume of } \\
\text { blood } \\
\text { exchanged }\end{array}$ & $\begin{array}{l}\text { Source of } \\
\text { blood } \\
\text { infused }\end{array}$ & $\begin{array}{l}0 \text { to } 1 \\
\text { hour }\end{array}$ & $\begin{array}{l}1 \text { to } 2 \\
\text { hours }\end{array}$ & $\begin{array}{l}3 \text { to } 4 \\
\text { hours }\end{array}$ \\
\hline $\begin{array}{l}\text { number } \\
\text { V-125 } \\
V-127 \\
V-129 \\
V-130 \\
V-131 \\
V-132 \\
V-133\end{array}$ & $\begin{array}{l}\text { kgm. } \\
12.5 \\
11.5 \\
14.6 \\
21.0 \\
22.7 \\
16.8 \\
22.7\end{array}$ & $\begin{array}{l}\text { liters } \\
1.62 \\
1.05 \\
0.84 \\
2.30 \\
2.80 \\
2.90 \\
1.53\end{array}$ & $\begin{array}{l}\text { sinute } \\
0.79 \\
0.60 \\
0.91 \\
3.56 \\
0.67 \\
1.34\end{array}$ & $\begin{array}{l}\text { kgm. } \\
1.51 \\
0.62 \\
0.57 \\
1.96 \\
2.84 \\
1.21 \\
1.17\end{array}$ & $\begin{array}{l}\text { ml. per kgm. } \\
38^{*} \\
30^{*} \\
34 \\
14.5 \\
22 \\
24 \\
15\end{array}$ & $\begin{array}{l}\text { same dog } \\
\text { same dog } \\
\text { same dog } \\
\text { same dog } \\
\text { other dogt } \\
\text { other dog } \\
\text { other dogt }\end{array}$ & $\begin{array}{l}\text { liter } \\
1.81 \\
0.46 \\
0.51 \\
2.40 \\
3.71 \\
1.24 \\
1.35\end{array}$ & $\begin{array}{c}\text { sinute } p \\
1.42 \\
0.60 \\
0.50\end{array}$ & $\begin{array}{l}\text { kgm. } \\
0.43\end{array}$ \\
\hline
\end{tabular}

* Transfused into jugular vein.

thetized dogs during the control period was greater than that noted by Wiggers (7) in anesthetized dogs. This emphasizes the need for caution in interpreting changes in cardiac output in unanesthetized animals. For this reason, experimental alterations in hematocrit were carried out only after a prolonged period of control observation had demonstrated the stability of the cardiac output. Fluctuations in cardiac output in shocked dogs, $\dagger$ Blood compatible. apart from the expected steady decline, were much less marked than in normal dogs.

\section{Effects on cardiac output of exchanges of blood}

In early experiments, the hematocrit was raised by exchanging arterial blood for packed red cells. A fall in cardiac output was noted after the first exchanges, which was out of proportion to the ele- 
TABLE V

Normal dogs

Effect on cardiac output and peripheral resistance* $(R)$ of raising hematocrit in stagest by bleeding from the femoral artery and simuliareously replacing an equal volume of packed red cells via the femoral vein

\begin{tabular}{|c|c|c|c|c|c|c|c|}
\hline & $\begin{array}{c}\text { Determina- } \\
\text { tion } \\
\text { number }\end{array}$ & Hematocrit & $\begin{array}{l}\text { Apparent } \\
\text { relative } \\
\text { viscosity }\end{array}$ & $\begin{array}{c}\text { Mean } \\
\text { arterial } \\
\text { pressure }\end{array}$ & $\begin{array}{l}\text { Cardiac } \\
\text { output } \neq\end{array}$ & $R^{*}$ & Remarks \\
\hline Dog V-50 & $\begin{array}{l}1 \\
2 \\
3 \\
4 \\
5 \\
6\end{array}$ & $\begin{array}{c}\text { per cent } \\
39 \\
43 \\
48 \\
54 \\
60 \\
68\end{array}$ & $\begin{array}{r}4.7 \\
5.1 \\
5.6 \\
7.1 \\
9.4 \\
15.2\end{array}$ & $\begin{array}{c}m m . H \varepsilon \\
105 \\
100 \\
105 \\
100 \\
95 \\
80\end{array}$ & $\begin{array}{c}\text { liters per } \\
\text { minute per } \\
\text { lo kzm. } \\
2.39 \\
0.93 \\
0.77 \\
0.52 \\
0.51 \\
0.39\end{array}$ & $\begin{array}{l}0.76 \\
1.71 \\
1.98 \\
2.19 \\
1.60 \\
1.09\end{array}$ & \\
\hline Dog V-57 & $\begin{array}{l}1 \\
2 \\
3 \\
4 \\
5 \\
6 \\
7 \\
8 \\
9\end{array}$ & $\begin{array}{l}42 \\
47 \\
48 \\
52 \\
54 \\
60 \\
64 \\
70 \\
70\end{array}$ & $\begin{array}{r}3.7 \\
4.0 \\
4.2 \\
4.7 \\
5.1 \\
7.1 \\
8.0 \\
10.2 \\
12.0\end{array}$ & $\begin{array}{l}120 \\
110 \\
115 \\
110 \\
115 \\
120 \\
110 \\
115 \\
100\end{array}$ & $\begin{array}{l}2.36 \\
3.21 \\
1.54 \\
1.21 \\
1.41 \\
1.21 \\
1.03 \\
0.78 \\
0.75\end{array}$ & $\begin{array}{l}1.11 \\
0.69 \\
1.44 \\
1.56 \\
1.30 \\
1.13 \\
1.08 \\
1.17 \\
0.90\end{array}$ & No exchange \\
\hline Dog V-59 & $\begin{array}{l}1 \\
2 \\
3 \\
4 \\
5 \\
6\end{array}$ & $\begin{array}{l}38 \\
44 \\
51 \\
60 \\
69 \\
73\end{array}$ & $\begin{array}{r}3.7 \\
4.6 \\
6.4 \\
9.2 \\
16.2 \\
23.0\end{array}$ & $\begin{array}{r}100 \\
100 \\
105 \\
110 \\
105 \\
85\end{array}$ & $\begin{array}{l}1.69 \\
1.55 \\
0.75 \\
0.56 \\
0.36 \\
0.36\end{array}$ & $\begin{array}{l}1.30 \\
1.14 \\
1.69 \\
1.73 \\
1.46 \\
0.83\end{array}$ & Red blood cells were washed \\
\hline Dog V-60 & $\begin{array}{l}1 \\
2 \\
3 \\
4 \\
5\end{array}$ & $\begin{array}{l}41 \\
47 \\
60 \\
72 \\
76\end{array}$ & $\begin{array}{r}4.3 \\
5.5 \\
8.2 \\
14.2 \\
14.6\end{array}$ & $\begin{array}{l}105 \\
105 \\
105 \\
120 \\
120\end{array}$ & $\begin{array}{l}1.70 \\
0.63 \\
0.46 \\
0.27 \\
0.35\end{array}$ & $\begin{array}{l}1.16 \\
2.46 \\
2.26 \\
2.54 \\
1.90\end{array}$ & $\begin{array}{l}\text { Red blood cells were washed } \\
\text { So exchange }\end{array}$ \\
\hline Dog V-102 & $\begin{array}{l}1 \\
2 \\
3 \\
4 \\
5 \\
6 \\
7\end{array}$ & $\begin{array}{l}40 \\
45 \\
47 \\
50 \\
56 \\
66 \\
76\end{array}$ & $\begin{array}{l}3.3 \\
3.6 \\
4.0 \\
4.2 \\
4.9 \\
6.5 \\
8.9\end{array}$ & $\begin{array}{r}120 \\
105 \\
100 \\
90 \\
90 \\
90 \\
80\end{array}$ & $\begin{array}{l}2.15 \\
1.54 \\
0.87 \\
1.40 \\
1.50 \\
1.03 \\
0.41\end{array}$ & $\begin{array}{l}1.37 \\
1.53 \\
2.32 \\
1.24 \\
0.99 \\
1.09 \\
1.77\end{array}$ & $\begin{array}{l}\text { Red blood cells were washed } \\
\text { Slight increase in blood } \\
\text { volume }\end{array}$ \\
\hline
\end{tabular}

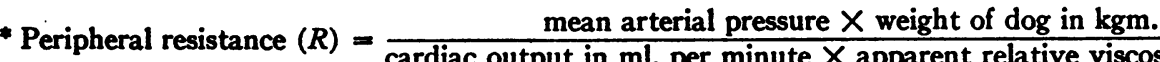

the mean value for $K$ in observations in 23 normal dogs (whose $R$ was assumed to be unity) was found to be 8.1 (see Table I). Using this value for $K, R$ was found to vary between 0.54 and 1.83 in 23 normal dogs.

† One-half hour was allowed to elapse between completion of exchange and subsequent cardiac output determination.

‡ Auricular blood sample obtained by passage of straight glass tube through external jugular vein.

vation in hematocrit produced. This drop in cardiac output presumably resulted from an increase in vasoconstriction (increase in $R$ ) which persisted for some time and which was thought to be the result of arterial hemorrhage. To test this point, dogs were bled from an artery and this blood (heparinized) was immediately reinjected intravenously without any significant net change in blood volume or hematocrit. Cardiac output determinations were made before and after such exchanges (Table III). The result in 10 of 12 dogs was a fall in cardiac output. When, on the other hand, an exchange was made of blood taken from one femoral vein and transferred to the other, 5 out of 7 dogs showed a rise in cardiac output (Table IV). Hence, it appears that less adverse disturbance of the hemodynamic equilibrium is produced by vein to vein exchanges. It should be noted, however, that in some of the early experiments to be reported, the arteriovenous exchange technique was used (Tables V and VIII). 





EFFECT ON CARDIAC OUTPUT AND PERIPHERAL RESISTANCE $(R)$ OF VARIATIONS IN HEMATOCRIT (VISCOSITY)

\section{A. Dogs with normal blood volume}

1. Arterio-venous exchange (Table V, Figure 1)

The hematocrit of normal dogs was raised in stages by exchanging packed red blood cells via a vein for whole blood removed from the femoral artery. Cardiac output determinations were performed $1 / 2$ hour after the completion of each exchange. The peripheral resistance $(R)$ was cal- culated from equation 3. The relation of cardiac output per $10 \mathrm{kgm}$. per $100 \mathrm{~mm}$. $\mathrm{Hg}$ blood pressure to the changes in blood viscosity is shown in Figure 1. Hyperbolic curves of constant peripheral resistance $(R)$ are also shown in Figures 1 and 2 so that shifts in $R$ in terms of these constants can be visualized.

The most striking feature of both the plot (Figure 1) and the table (V) is the rapid drop in cardiac output before any significant rise in blood viscosity is achieved. This suggests a rise in $T P R$ due to a rise in $R$, which, in fact, by calcu-

TABLE VI

Normal dogs

Effect on cardiac output and peripheral resistance* $(R)$ of raising hematocrit in stagest by bleeding from the femoral vein and simultaneously replacing an equal volume of packed red cells via the femoral vein

\begin{tabular}{|c|c|c|c|c|c|c|c|}
\hline Dog & $\begin{array}{l}\text { Determi- } \\
\text { nation } \\
\text { number }\end{array}$ & Hematocrit & $\begin{array}{l}\text { Apparent } \\
\text { relative } \\
\text { viscosity }\end{array}$ & $\begin{array}{c}\text { Mean } \\
\text { arterial } \\
\text { pressure }\end{array}$ & $\begin{array}{l}\text { Cardiac } \\
\text { output } \ddagger\end{array}$ & $R^{*}$ & Remarks \\
\hline $\begin{array}{l}\text { number } \\
V-131^{* *}\end{array}$ & $\begin{array}{l}1 \\
2 \\
3 \\
4 \\
5 \\
6\end{array}$ & $\begin{array}{c}\text { per cent } \\
47 \\
51 \\
56 \\
61 \\
68 \\
42\end{array}$ & $\begin{array}{l}5.2 \\
5.4 \\
6.2 \\
7.8 \\
9.0 \\
4.5\end{array}$ & $\begin{array}{l}m m . H g \\
130 \\
130 \\
130 \\
130 \\
130 \\
130\end{array}$ & $\begin{array}{c}\text { liters per } \\
\text { minute per } \\
10 \mathrm{kgm} \text {. } \\
2.84 \\
3.70 \\
1.56 \\
1.16 \\
0.79 \\
1.48\end{array}$ & $\begin{array}{l}0.71 \\
0.53 \\
1.08 \\
1.16 \\
1.49 \\
1.58\end{array}$ & $\begin{array}{l}\text { Preceded by whole blood exchange } \\
\text { Preceded by plasma exchange }\end{array}$ \\
\hline$V-132 * *$ & $\begin{array}{l}1 \\
2 \\
3 \\
4 \\
5\end{array}$ & $\begin{array}{l}54 \\
63 \\
70 \\
74 \\
40\end{array}$ & $\begin{array}{r}6.2 \\
7.6 \\
9.7 \\
11.5 \\
4.2\end{array}$ & $\begin{array}{l}120 \\
110 \\
110 \\
115 \\
110\end{array}$ & $\begin{array}{l}1.24 \\
1.95 \\
0.91 \\
0.68 \\
1.58\end{array}$ & $\begin{array}{l}1.24 \\
0.60 \\
1.01 \\
1.20 \\
1.34\end{array}$ & Preceded by plasma exchange \\
\hline$V-133^{* *}$ & $\begin{array}{l}1 \\
2 \\
3 \\
4 \\
5 \\
6\end{array}$ & $\begin{array}{l}62 \\
65 \\
70 \\
74 \\
78 \\
46\end{array}$ & $\begin{array}{r}7.2 \\
7.7 \\
9.3 \\
10.9 \\
13.8 \\
7.2\end{array}$ & $\begin{array}{l}140 \\
130 \\
125 \\
120 \\
130 \\
130\end{array}$ & $\begin{array}{l}1.34 \\
1.35 \\
1.36 \\
0.87 \\
1.09 \\
1.14\end{array}$ & $\begin{array}{l}1.18 \\
1.01 \\
0.80 \\
1.02 \\
0.70 \\
1.28\end{array}$ & $\begin{array}{l}\text { Preceded by whole blood exchange } \\
\text { Preceded by plasma exchange }\end{array}$ \\
\hline V-137 & 1 & $\begin{array}{l}53 \\
72\end{array}$ & $\begin{array}{r}6.4 \\
11.5\end{array}$ & $\begin{array}{l}100 \\
100\end{array}$ & $\begin{array}{l}1.23 \\
1.05\end{array}$ & $\begin{array}{l}1.03 \\
0.67\end{array}$ & \\
\hline V-138 & $\begin{array}{l}1 \\
2\end{array}$ & $\begin{array}{l}50 \\
70\end{array}$ & $\begin{array}{l}4.5 \\
8.6\end{array}$ & $\begin{array}{l}130 \\
110\end{array}$ & $\begin{array}{l}2.80 \\
0.29\end{array}$ & $\begin{array}{l}0.84 \\
3.56\end{array}$ & \\
\hline V-139 & 1 & $\begin{array}{l}48 \\
62\end{array}$ & $\begin{array}{r}6.0 \\
10.4\end{array}$ & $\begin{array}{l}100 \\
110\end{array}$ & $\begin{array}{l}0.99 \\
0.44\end{array}$ & $\begin{array}{l}1.37 \\
1.95\end{array}$ & \\
\hline V-140 & $\begin{array}{l}1 \\
2\end{array}$ & $\begin{array}{l}48 \\
66\end{array}$ & $\begin{array}{l}5.9 \\
8.3\end{array}$ & $\begin{array}{l}110 \\
125\end{array}$ & $\begin{array}{l}2.75 \\
2.51\end{array}$ & $\begin{array}{l}0.55 \\
0.49\end{array}$ & \\
\hline V-141 & $\begin{array}{l}1 \\
2\end{array}$ & $\begin{array}{l}41 \\
68\end{array}$ & $\begin{array}{r}4.6 \\
10.8\end{array}$ & $\begin{array}{l}130 \\
140\end{array}$ & $\begin{array}{l}1.24 \\
0.43\end{array}$ & $\begin{array}{l}1.84 \\
2.44\end{array}$ & \\
\hline
\end{tabular}

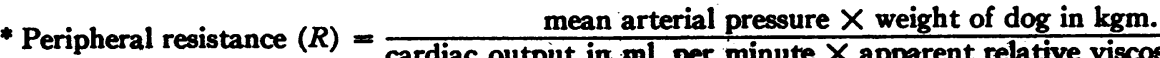

cardiac output in ml, per minute $X$ apparent relative viscosity of blood $\times K$, where the mean value for $K$ in observations in 23 normal dogs (whose $R$ was assumed to be unity) was found to be 8.1 (see Table I). Using this value for $K, R$ was found to vary between 0.5 and 1.8 in 23 normal dogs.

t One-half hour was allowed to elapse between completion of exchange and subsequent cardiac output determination.

† Auricular blood sample obtained through inlying catheter.

* The final determination in these dogs represents a departure from the procedure indicated in the table title in that the hematocrit was lowered in one step by the exchange of plasma for whole blood. 


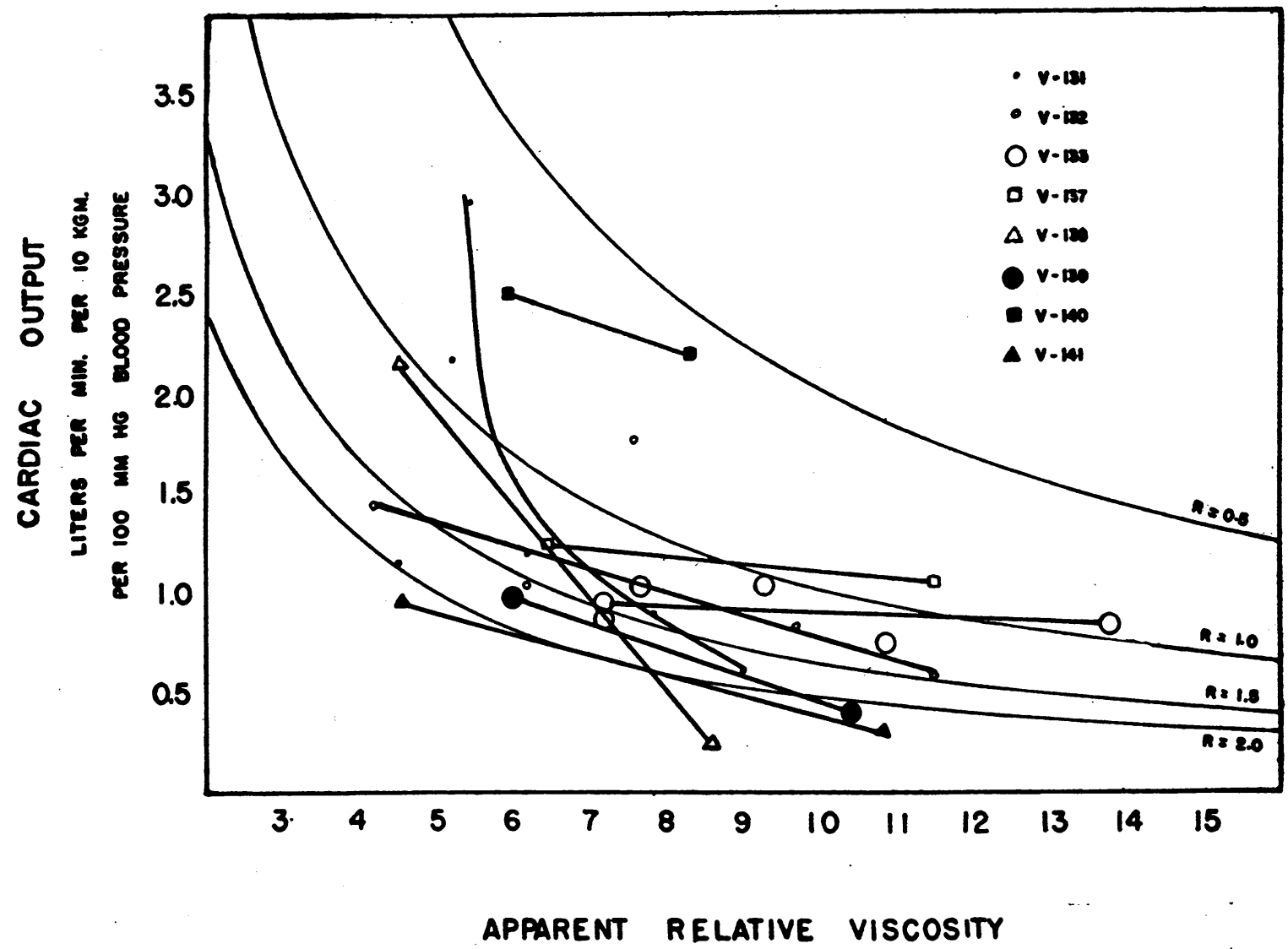

Fig. 2. Normal Blood Volume Veno-venous Exchanges Raising Hematocrit

lation, was found to have risen after the first or second exchange. This rise in $R$ presumably signifies vasoconstriction persisting after arterial hemorrhage.

After the first few exchanges, relatively small changes in cardiac output were produced by further increases in hematocrit. (Venous pressure measurements, both central and peripheral, were normal.) In the higher ranges of hematocrit, $R$ remained relatively constant at an abnormally high level, and the cardiac outputs correspondingly were abnormally low.

If both $R$ and the blood pressure remain constant, the hyperbolic shape of the curves for constant $R$ indicates that in normal dogs with low cardiac output levels, relatively large changes in viscosity are required to effect changes in cardiac output. These curves also indicate the extent of the changes in cardiac output to be expected at any given viscosity from changes in $R$ at constant blood pressure. From Table V, it is evident that the blood pressure of any given dog remained fairly constant (10 to $20 \mathrm{~mm}$. $\mathrm{Hg}$ change) in spite of marked changes in cardiac output, viscosity, and vasoconstriction. From Figure 1, it is also evident that in the low cardiac output range there was but little compensatory adjustment (lowering) of $R$ with increasing viscosity.

\section{Veno-venous exchange (Table VI, Figure 2)}

The hematocrit of normal dogs was raised in stages by an exchange between veins of packed red blood cells for whole blood. When blood flow was low, aspiration of blood was facilitated by massage and passive motion of the leg and foot.

In contrast to dogs whose exchanges involved arterial hemorrhage, these dogs showed, with 2 exceptions, a less steep drop in cardiac output with increase in viscosity (Figure 2). There was a greater tendency for $R$ to drop, in compensation for rise in viscosity, with maintenance of cardiac output, than was noted in arterio- 
ARNOLD M. SELIGMAN, HOWARD A. FRANK, AND JACOB FINE

\begin{tabular}{|c|c|c|c|c|c|}
\hline & 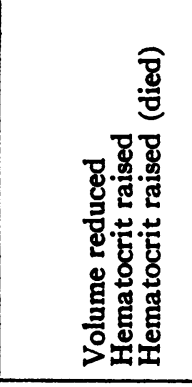 &  & 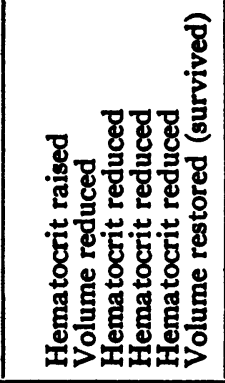 & 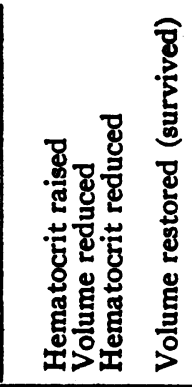 &  \\
\hline$\approx$ & 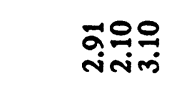 & |స్తి & 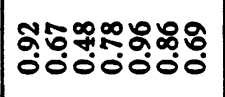 &  & 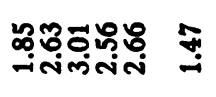 \\
\hline 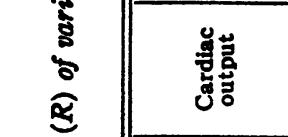 & 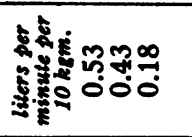 & Tु్ & 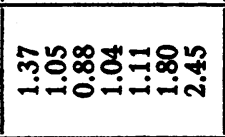 & సేద్గిస్ స్ & స్తిర్తిల్లిం్త స్త \\
\hline 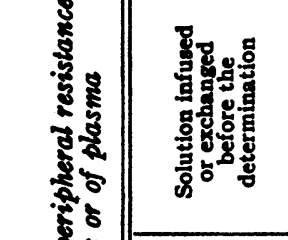 &  & 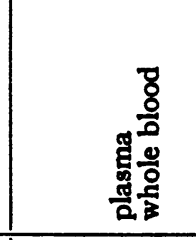 & 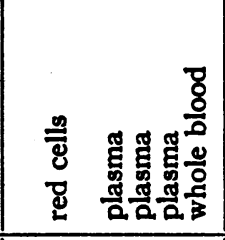 & 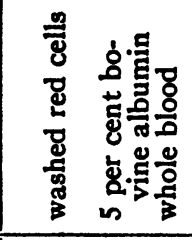 & 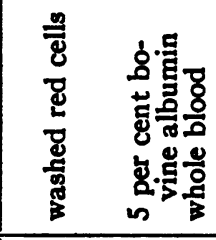 \\
\hline 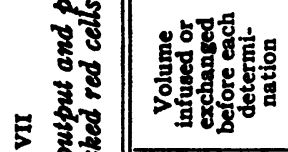 & $=$ & స్లెల & $\stackrel{\infty}{\infty} \approx \approx \approx \infty$ & क హ & 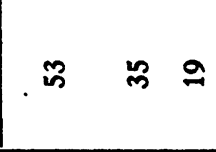 \\
\hline 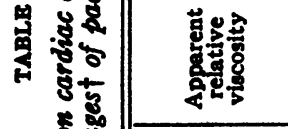 &  & 我吕 & 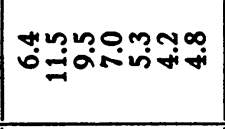 &  & 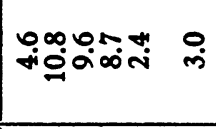 \\
\hline 兽 & ระ⿱ &  & 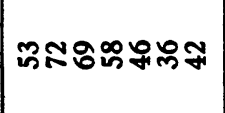 & 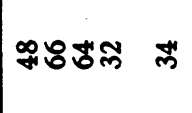 & 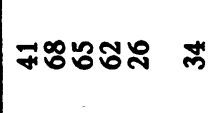 \\
\hline 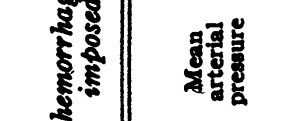 & 물요 & ్ㅕ 요 & ర్తిర్లRRR:8 & ㅇㅗㅀㅛ శ్తి &  \\
\hline 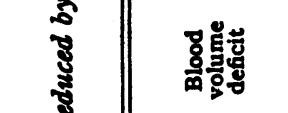 & 话 & $0_{\vec{m}} \vec{m} 0$ & ○ & อ๐กส 0 & oomag 0 \\
\hline 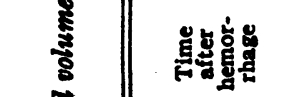 & 喜 - & On in & 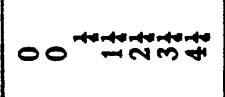 & $00= \pm$ & $00^{m}=\pi$ \\
\hline ด̆ & $\stackrel{5}{\stackrel{3}{7}}$ & $\mid \frac{8}{3}$ & $\frac{m}{3}$ & $\frac{9}{7}$ & $\mid \begin{array}{l}7 \\
\end{array}$ \\
\hline 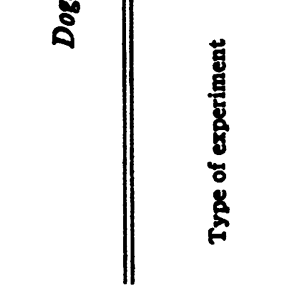 & 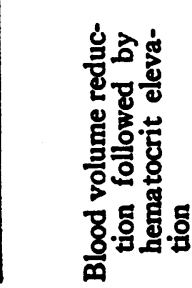 & 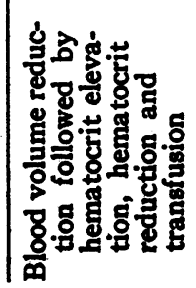 & 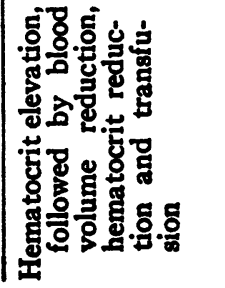 & & \\
\hline
\end{tabular}


venous exchange experiments. One might conclude, therefore, that normal dogs with a normal blood volume can compensate for rises in hematocrit by drops in peripheral resistance $(R)$ so as to maintain cardiac output and blood pressure, providing the peripheral resistance has not been raised by an increase in vasoconstriction from a stimulus such as arterial hemorrhage. Other influences producing vasoconstriction, such as pain, anxiety, pressor substances liberated from heparinized blood, constrictor reflexes secondary to auricular catheterization or manipulation of blood vessels may have been operating in some of these experiments.

In 3 of these dogs, the hematocrit was reduced to lower than the starting level by a final exchange of plasma for whole blood. In every case the cardiac output rose but not to the expected level. Since the peripheral resistance $(R)$ remained elevated, stimuli other than arterial bleeding were operating in these dogs to maintain vasoconstriction and so oppose spontaneous adjustments of $R$ to varying viscosity.

These observations are in consonance with the general experience that animals react less and less well to repeated hemorrhages, which are fully replaced.

\section{B. Dogs with blood volume reduced by hemorrhage}

\section{Elevation of hematocrit after hemorrhage (Table VII)}

In one experiment in which the hematocrit was raised in two stages after inducing hemorrhage (18 ml. per $\mathrm{kgm}$.), cardiac output dropped to less than half the level produced by the hemorrhage alone. The peripheral resistance increased after the first increase in hematocrit and remained high after the second. In contrast to the dogs with normal blood volume and increased viscosity, whose blood pressure was sustained whatever the cardiac output or $T P R$, the blood pressure in this experiment then dropped from 70 to $55 \mathrm{~mm}$. $\mathrm{Hg}$. The removal of $6 \mathrm{ml}$. of auricular blood at the time of the last determination of cardiac output resulted in death, probably because the cardiac output at that time was at the lowest limit compatible with life, even though the blood pressure was still $55 \mathrm{~mm}$. $\mathrm{Hg}$. A dog in hemorrhagic shock with normal blood viscosity seldom dies at this blood pressure. This demonstrates the deceptiveness of the blood pressure as an index of blood flow in the shocked animal with a high blood viscosity.

In this experiment, the compensatory mechanism for maintaining the blood pressure, i.e., raising the peripheral resistance, appears to have failed because the inadequate blood volume had reduced cardiac output to a critical level. The high blood viscosity aggravated the situation by decreasing cardiac intake and, therefore, output still further. The fall in cardiac output was out of proportion to the rise in $T P R$ and, therefore, blood pressure was not sustained.

\section{Hemorrhage accompanied by elevation of he- matocrit and followed by reduction of hemato- crit and transfusion (Table VII, Figure 3)}

To avoid confusing the effect on cardiac output of stepwise increase in viscosity with the spontaneous decline which occurs with time in an animal with low blood volume, the hematocrit was raised to the maximum level simultaneous with the reduction in blood volume $(\mathrm{V}-136)$.

The hematocrit was raised in one step simultaneous with the production of hemorrhage by the removal of a larger volume of whole blood than was returned as packed red cells. The resulting cardiac output was one-third of the previous value and the peripheral resistance increased. When the hematocrit was then reduced, without change in blood volume, by exchange of plasma for an equal volume of whole blood, the cardiac output rose almost to normal. The peripheral resistance dropped to well below the starting level at the expense of the blood pressure, which dropped from 90 to $40 \mathrm{~mm}$. Hg. Restoration of normal blood volume, with little change in hematocrit, resulted in a further increase in cardiac output, a further decrease in peripheral resistance, and a partial restoration of blood pressure.

In the course of the experiment, the dog remained for a period of 3 hours with very low cardiac output, which resulted in sufficient deterioration to produce "irreversibility" (11) to the final transfusion. This low cardiac output, induced by increased viscosity along with reduction in blood volume, persisting for 3 hours at a 
blood pressure of $90 \mathrm{~mm}$. $\mathrm{Hg}$, produced as much deterioration as we have noted in hemorrhagic shock with normal blood viscosity after a 2- to 3hour period at a pressure of $30 \mathrm{~mm}$. $\mathrm{Hg}$. This is evidence that deterioration is related more closely to the cardiac output than to the level of blood pressure.

3. Elevation of hematocrit followed by hemorrhage, reduction of hematocrit, and transfusion (Table VII, Figure 3)

The length of time required in the foregoing experiment to perform the exchanges necessary to effect the maximum rise in hematocrit in a single step, simultaneous with the reduction in blood volume, was still too long to permit a distinction between the deleterious effect of time in an animal with low volume and normal hematocrit, from the deleterious effect of low volume and high viscosity.

In the following experiments (V-137, V-140, $\mathrm{V}-141$ ), therefore, the hematocrit was raised to its maximum level before the blood volume was reduced. The rise in hematocrit alone resulted in a fall in cardiac output of moderate degree in dogs $\mathrm{V}-137$ and V-140 and of severe degree in dog $\mathrm{V}-141$. The peripheral resistance $(R)$ decreased slightly in the first two, but doubled in dog V-141. Moderate hemorrhage (18 to $22 \mathrm{ml}$. per kgm.) was then instituted, and a further drop in cardiac output resulted. This drop was of moderate degree in dog V-137 and was accompanied by a drop in $R$ and in blood pressure. In the other two dogs the drop in cardiac output was severe. There was a marked rise in $R$ and the blood pressure drop was moderate.

Bovine albumin or plasma was then exchanged for whole blood. In dog V-137 the decrease of hematocrit was performed stepwise without change in blood volume. This resulted in progressive increase in cardiac output to a level higher than the starting level, and transfusion produced almost double the original cardiac output. Blood pres-

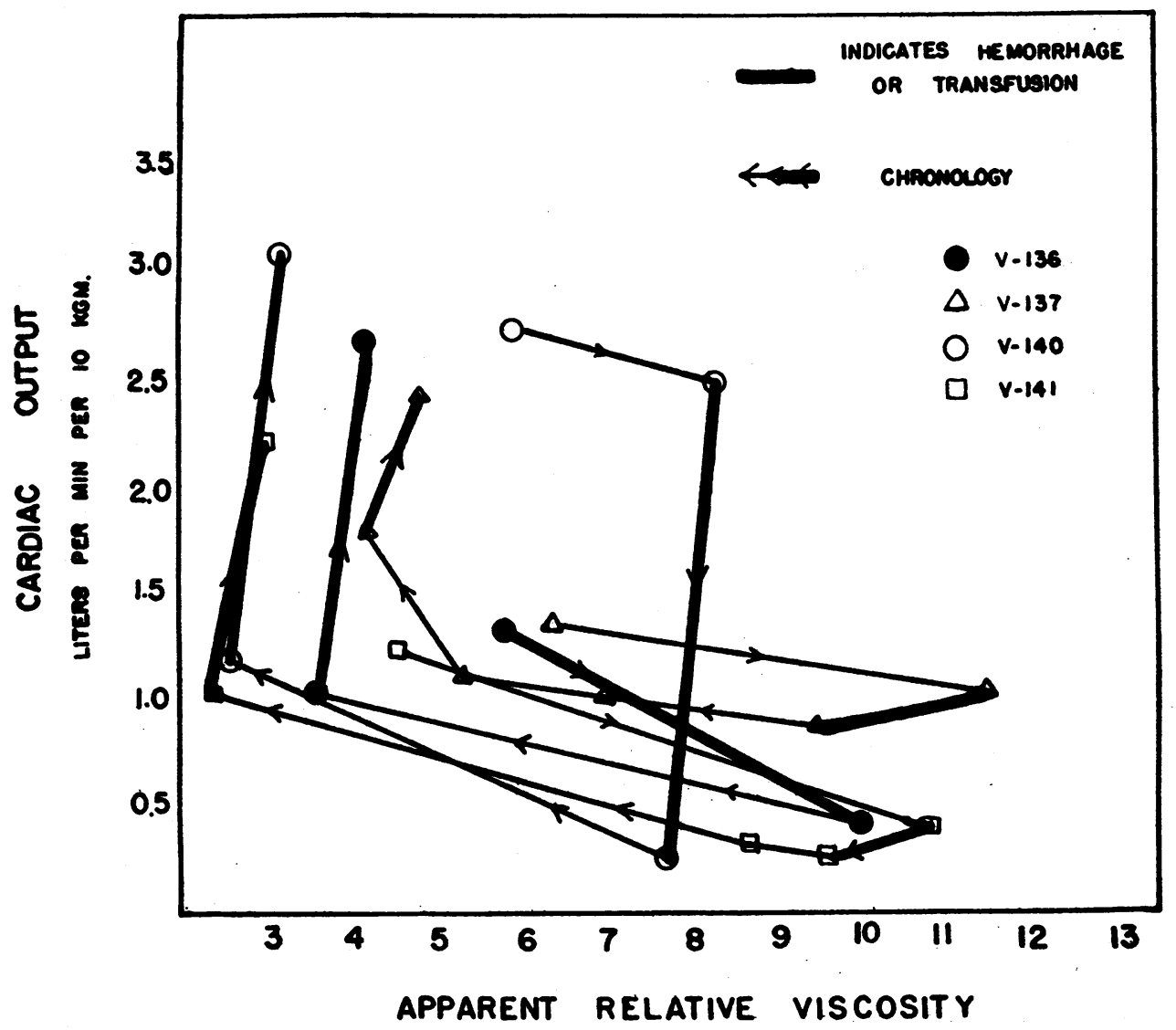

Fig. 3. Hematocrit Altered by Veno-venous Exchanges at Normal and Low Blood Volumes 
sure changes paralleled the rise in cardiac output, and the peripheral resistance remained unchanged. In dog V-140, reduction of hematocrit was performed in one step without change in blood volume. Cardiac output increased though not to the normal level. Transfusion increased cardiac output to above the normal level. The peripheral resistance gradually decreased to near normal after the transfusion. In dog V-141 the results were similar.

A study of Figure 3 indicates the degree of restoration of cardiac output achieved by restoring the original blood viscosity without restoring the deficiency in blood volume. This amounted to 10 to 50 per cent of the total fall in cardiac output produced by the hemorrhage and by the increase in viscosity. Further reduction of the high viscosity to below the original level restored the original cardiac output in 2 of 3 cases. Thereafter, restoration of blood volume by transfusion produced cardiac output levels well above the starting levels in all these dogs.

Since the fall in cardiac output depends on the decrease in blood volume, as well as on the increase in viscosity, the quantitative effect of lowering viscosity will be influenced by the extent of the blood volume deficiency. In these experiments, the extent of the hemorrhage was purposefully not severe (18 to $22 \mathrm{ml}$. per $\mathrm{kgm}$.), since dogs with high blood viscosity and low blood volume are in too precarious a state to tolerate even small blood withdrawals or other manipulations. In Figure 3 it will be noted that while the slopes of decline in cardiac output with increasing viscosity are almost the same for dogs with normal as for dogs with reduced blood volume, the percentage of fall in cardiac output at reduced blood volume is much greater than at normal blood volume.

\section{Dogs with blood volume reduced by the tourniquet technique}

In tourniquet shock, there is a rapid fall in blood volume and a simultaneous rise in blood viscosity due to a loss of plasma into the extremities upon release of the tourniquets. This situation is analogous to the foregoing experiments (Section B) in which blood volume was reduced and viscosity increased in an otherwise intact animal.
Changes in cardiac output during development of tourniquet shock (Table VIII)

Cardiac outputs were determined just before removal of tourniquets in 6 dogs and found to be within normal limits in 5 . These observations were repeated in 2 dogs at $1 / 4$ hour, in 2 at $1 / 2$ hour, and in 2 at 1 hour intervals after removal of the tourniquets. The cardiac output fell to 50 per cent of the original in the $1 / 4$ and $1 / 2$ hour determinations (Dogs V-104, 105, 108, and 109) and to 25 per cent of the original in the 1 hour determinations (Dogs V-37 and 41). These changes in cardiac output are comparable to those found in the experiments of Section B although it is clear that a close quantitative comparison is not possible because we did not determine the extent of the blood volume loss in the tourniquet experiments. The maximum rise in hematocrit was usually found to occur within 1 hour after removal of the tourniquets. Only slight further rises occurred after this. Large decreases in blood volume in tourniquet shock have been demonstrated, but they cannot be accurately estimated from the change in hematocrit alone. It is probable that the blood volume loss exceeded that produced in the experiments of Section B.

\section{Reduction of hematocrit and restoration of} blood volume in stages by infusion of 5 per cent bovine albumin (Table VIII, Section A)

In 2 experiments, after the hematocrit had risen to 65 per cent, and the blood pressure had dropped to 70 to $80 \mathrm{~mm}$. $\mathrm{Hg}$, the hematocrit was reduced in stages by infusion of 5 per cent bovine albumin solution. Both the hematocrit and blood volume were overcorrected to a considerable extent in this way. The cardiac outputs increased with each infusion and exceeded the original values when subnormal hematocrits were produced.

\section{Restoration of blood volume by transfusion, followed by reduction of hematocrit by plasma exchange (Table VIII, Section B)}

In these experiments, an attempt was made to evaluate separately the effects on cardiac output of the restoration of blood volume and of the restoration of hematocrit. 







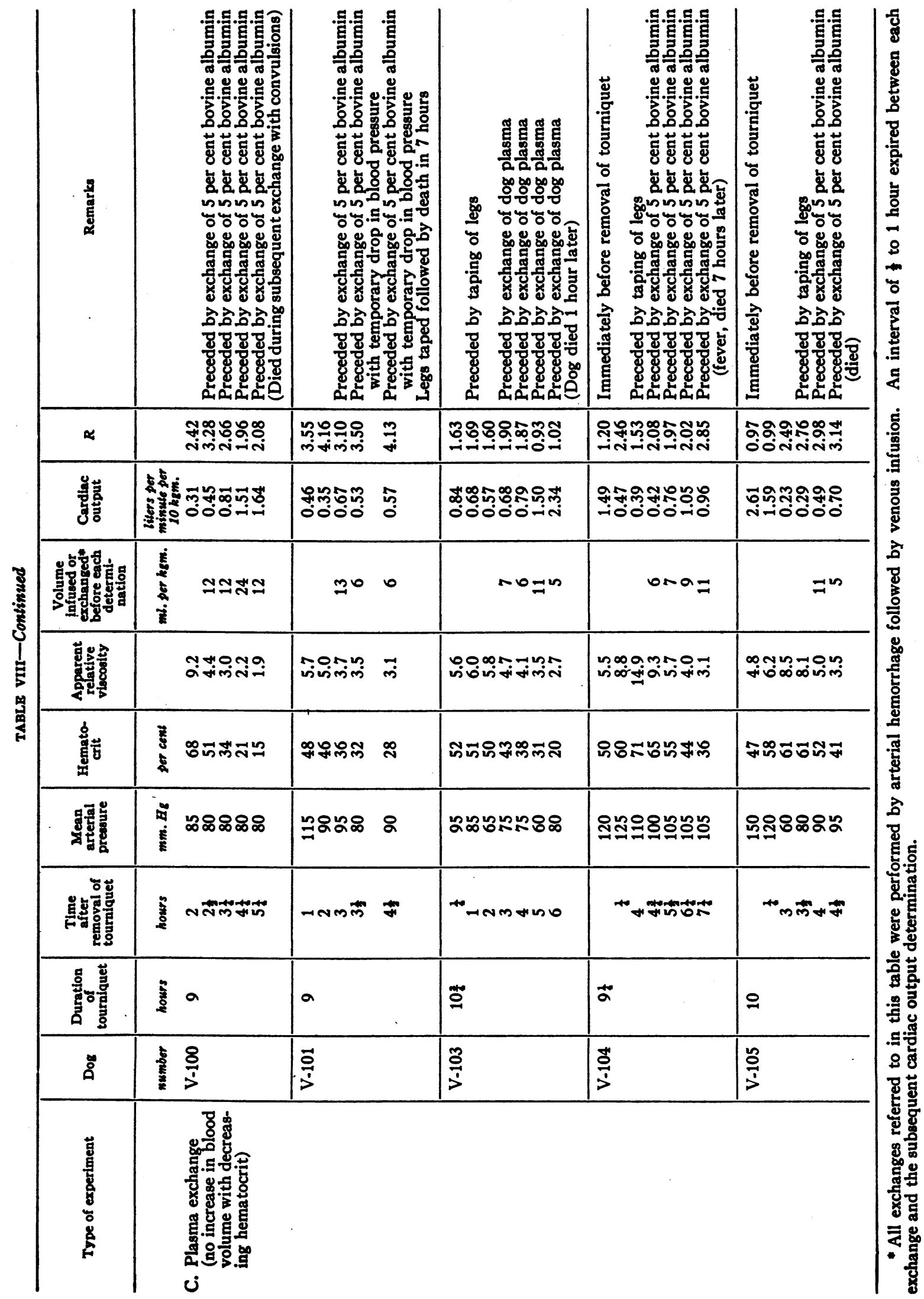




\section{(a) Restoration of blood volume}

The volume of blood or red cells necessary to restore blood volume was taken empirically as $\mathbf{5}$ per cent of the body weight. It was felt that this volume would more than insure restoration of volume, even if some leakage into traumatized areas continued. A volume of packed red cells equal to 5 per cent of the body weight was infused in 3 dogs (dogs V-108, V-109, V-110). An attempt was made to prevent continuing loss of plasma into the extremities by taping the legs just before the infusion. The hematocrit rose in all 3 dogs.

In dog V-108 cardiac output was restored to the starting level even though the high blood viscosity was doubled by the injection of red cells. The blood pressure was also nearly doubled. The marked improvement in cardiac output was presumably due to the increase in blood volume and to the great reduction ( 75 per cent) in peripheral resistance $(R)$.

In dog V-110 the cardiac output was doubled but did not reach the normal level. The blood pressure was almost doubled, the viscosity was more than doubled, and again the peripheral resistance was reduced by 70 per cent.

Only a slight improvement in cardiac output occurred following the restoration of blood volume in dog V-109. The blood pressure and viscosity rose, but the peripheral resistance remained high.

Dog V -49 received whole blood rather than packed red cells in a dose of 3 per cent of the body weight. No significant improvement in cardiac output occurred. The legs in this dog were not taped. The failure of this dog to respond may have been due to insufficient restoration of blood volume.

The favorable response in cardiac output of the first 3 dogs indicates that the animal which has been in tourniquet shock can, like the normal dog, compensate for an increased blood viscosity, if blood volume is restored, by lowering peripheral resistance.

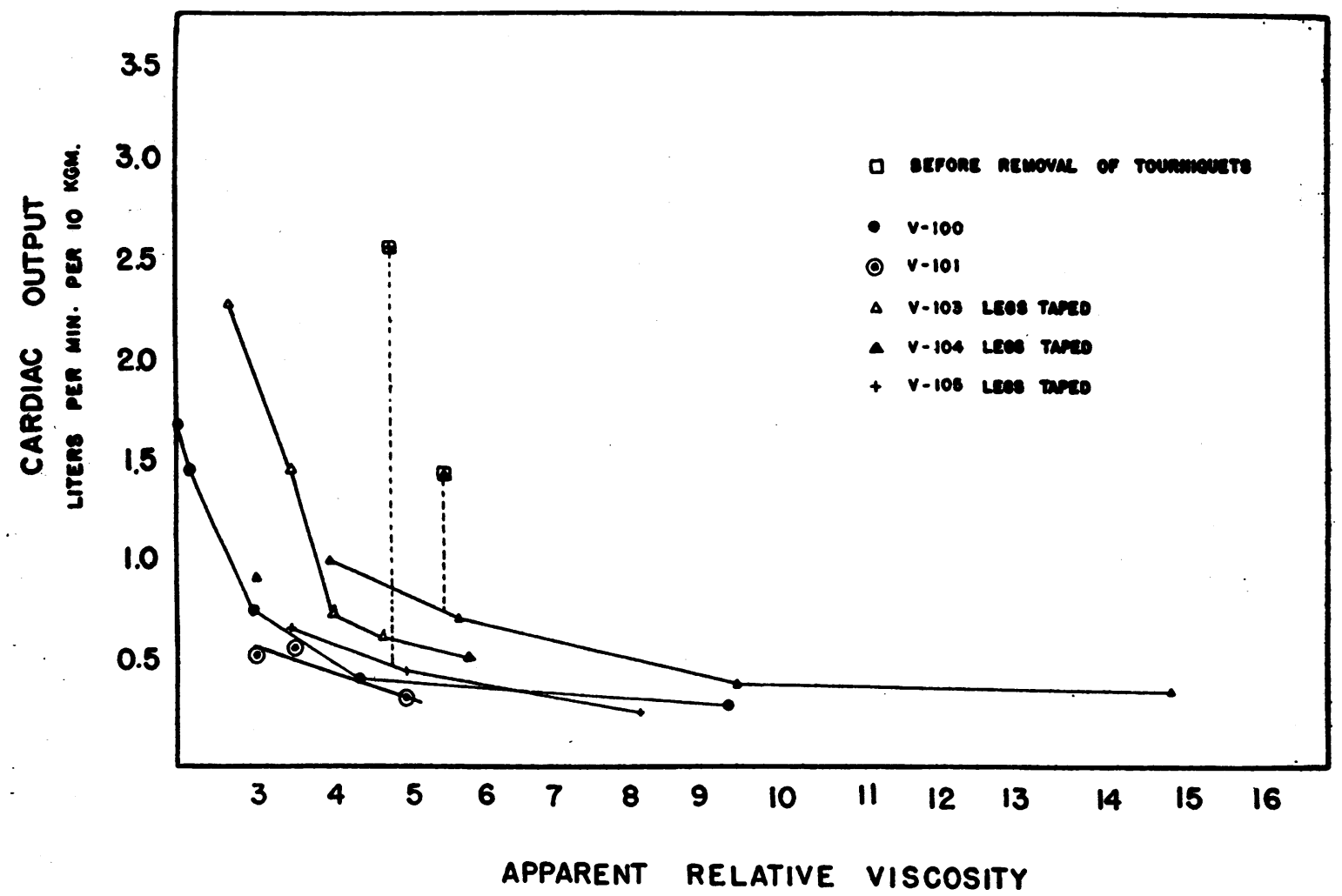

Fig. 4. Blood Volume Reduced by Tourniguets Arterio-venous Exchanges Lowering Hematocrit 


\section{(b) Reduction in hematocrit}

In all of the 4 dogs discussed in the previous section, plasma was then exchanged volume for volume for whole blood. Two dogs showed no rise in cardiac output as a result of lowering the hematocrit, 1 showed a slight improvement, and in 1 the cardiac output doubled. The expected favorable response to reduction of viscosity did not occur, and all 4 dogs died. This, we believe is due to the fact that these dogs had been maintained, prior to transfusion and plasma exchange, at cardiac outputs of 20 to 25 per cent of normal for at least 3 to 4 hours at blood pressures of 70 to $80 \mathrm{~mm}$. $\mathrm{Hg}$. As reported in a previous publication (1), this combination of circumstances in tourniquet shock results in "irreversibility" (11).

\section{Reduction in hematocrit by 5 per cent albumin} exchange, without restoration of blood volume (Table VIII, Section C, Figure 4)

The legs of 5 dogs in tourniquet shock were taped just before 5 per cent albumin was exchanged for whole blood without altering blood volume. The response in cardiac output to reduction in viscosity was poor in all, except that in 2 a good response was obtained when very low hematocrits ( 15 to 20 per cent) were reached (Figure 4). These experiments indicate that in untreated tourniquet shock, inadequate volume is more responsible than high viscosity for the low cardiac output and the high peripheral resistance.

At comparable blood pressure levels, these dogs in tourniquet shock showed the same low range of cardiac output as did those in hemorrhagic shock in which the hematocrit was raised ( $c f$. ., Figures 3 and 4 ). But, at these comparable ranges of cardiac output the viscosity was lower in the tourniquet shock dogs. This indicates a greater degree of vasoconstriction in the tourniquet shock dogs. This may be due to a greater blood volume loss in tourniquet shock than we produced in the bled dogs, or to vasoconstrictor substances arising in the area of trauma (12).

Although the cardiac output of dogs in tourniquet shock can be restored to normal by a marked reduction in hematocrit (to levels of 15 to 20 per cent), survival is not achieved by this procedure alone. Blood volume must also be restored.

\section{DISCUSSION}

The foregoing data with reference to changes in peripheral resistance $(R)$ perforce are not based on direct measurements, but largely on derivation from an equation which includes a constant $(K)$ that is subject to considerable variation. The data however are sufficiently conclusive in spite of these defects to indicate trends or approximations that are sufficient for our purposes.

Although the concentration of red cells is the largest factor determining the viscosity of blood as measured in a tube, the viscosity cannot be inferred from the hematocrit, as is obvious from an inspection of the tables. Furthermore, constancy of viscosity cannot be assumed even when the composition of the blood is not knowingly altered. The character and concentration of the plasma proteins are, next to the hematocrit, the most significant factors influencing blood viscosity. It is clear that in experiments and in clinical situations involving infusion therapy, the blood viscosity may be significantly altered by change in red cell concentration and by change in plasma protein concentration. Plasma viscosity may be increased by dehydration, by the infusion of concentrated plasma protein, or the higher molecular weight fractions of gelatin.

Of the two factors composing total peripheral resistance $(T P R)$, the viscosity cannot be readily altered by the organism in order to maintain homeostasis of flow. Following hemorrhage, some extracellular fluid is mobilized which results in a slight lowering of viscosity, and splenic contraction results in some elevation of viscosity. Even when the viscosity is high, splenic contraction may occur (13). The peripheral resistance $(R)$, on the other hand, is readily altered by vasoconstrictor and vasodilator mechanisms in normal and pathological states. From our experiments and others, it appears that the organism attempts to maintain blood pressure above a critical level. This is done by altering peripheral resistance $(R)$. The effectiveness of vasoconstriction in maintaining flow is dependent, however, on the blood viscosity, on the blood volume, and finally on the efficiency of heart action.

According to Poiseuille's equation, the higher the viscosity of blood, the higher the pressure necessary to maintain flow at a given peripheral 
resistance. If the resistance is lowered in inverse proportion to the rise in viscosity, blood pressure does not need to be raised to maintain flow. But, if blood volume or volume return to the heart is inadequate, an effective blood pressure cannot be maintained by the heart, and if the deficiency is severe enough, the blood pressure will drop below the critical level.

Failure to maintain adequate blood pressure can occur even in the presence of a normal blood volume, if heart action fails. The work of the heart may be represented, as a first approximation, by the equation

$$
\begin{aligned}
W & =O \times P \\
O & =\text { cardiac output and } \\
P & =\text { mean aortic pressure. }
\end{aligned}
$$$$
\text { where } \quad O=\text { cardiac output and }
$$

From Poiseuille's equation, it follows that the only way an increasing viscosity operates to increase the work of the heart is by requiring a higher blood pressure to maintain the cardiac output at an unaltered peripheral resistance $(R)$ : i.e., $P$ must rise with $\eta$ if $O$ and $R$ are constant. However, if a compensatory decrease in $R$ occurs with elevation in viscosity, the blood pressure $(P)$ need not rise to maintain cardiac output, and the work of the heart is not increased. If, on the other hand, blood pressure and peripheral resistance remain unaltered, a rise in viscosity will drop the cardiac output and thereby reduce the work of the heart. The concept that a rise in viscosity necessarily increases the work of the heart is not valid because of the concomitant variability of $R$ and $P$.

It has been stated (13), in experiments on shock resulting from plasmapheresis, that "some of our animals with high hematocrit and wellsustained blood pressure collapsed rapidly and died without warning, as though the heart, exhausted by attempts to force viscous blood through the vascular system, suddenly gave out entirely." It is implied (13) that highly viscous blood becomes the single determining factor, which, by imposing a critical load that the heart is unable to meet, is the cause of death. This is a characterization of the circumstances of sudden death which is at variance with what we interpret the hemodynamic situation to be. In these experiments (13), $R$ and $P$ and $\eta$ are all high. Indeed, blood viscosity is increasing, but cardiac output is falling as is the blood pressure. The work of the heart does not increase unless the blood pressure or the cardiac output goes up. We have noticed the same phenomenon and have precipitated such sudden collapse and death under similar conditions by removing $5 \mathrm{ml}$. of blood from the right auricle. Sudden death in the above-mentioned experiments (13) was due in our opinion to a critical, though slight, drop in cardiac output. (The critical level of cardiac output is higher in nembutalized than in unanesthetized or morphinized dogs.)

Under conditions of reduced blood volume, as in tourniquet shock or in hemorrhagic shock in which the hematocrit is artificially elevated, the increased blood viscosity at any given blood pressure level produces a fall in cardiac output with resulting poorer tolerance to further blood loss and more rapid development of "irreversibility" (11). Cardiac outputs reach critical limits at higher blood pressures than would be the case where blood viscosity is not elevated. These conclusions were reached by us in our experience with tourniquet shock (1) and from the data of this paper on hemorrhagic shock with increased hematocrit. They are in agreement with other data (13) in shock due to progressive plasmapheresis. In these experiments (13), the average cardiac output just before death was higher (0.9 liters per square meter per minute) than in our experiments because of the added factor of nembutal anesthesia.

It has been found (14) that the blood volume lost into the extremities in tourniquet shock was much less than that required to produce a corresponding severity of shock in dogs subjected to hemorrhage. These investigators confirm our observation (1) that the dog is in a precarious state even while the blood pressure is at a relatively satisfactory level. They conclude that nervous or humoral factors are involved in the creation of a deeper degree of shock than either the blood pressure or blood volume loss can account for. In reaching this conclusion, they omit consideration of cardiac output and of hematocrit. We have explained the discrepancy between tourniquet and hemorrhagic shock at comparable levels of blood pressure and blood volume deficiency by data showing that in tourniquet shock the cardiac output is critically depressed at much higher levels 
of blood pressure than in hemorrhagic shock, and this depression is due in large part to the higher hematocrit in tourniquet shock.

The circulating dynamics of our animals may be compared to those prevailing in human polycythemia vera. At hematocrits ranging from 66 to 76, patients were found to have normal blood pressure, normal cardiac output, and normal work of the heart (15). It follows from Poiseuille's formula that in polycythemia vera, the peripheral resistance $(R)$ should become less as the viscosity rises. The fall in cardiac output expected from the rise in viscosity is avoided by the compensation resulting from the fall in $R$. The reduction in $R$, furthermore, is facilitated in polycythemia vera by the increase in blood volume, which does not occur in acute experiments.

The lethal effects of raising the hematocrit of normal unanesthetized dogs to 70 to 80 per cent by daily exchanges over a period of 8 to 10 days have been reported (16). Our results were similar in normal dogs whose hematocrit was raised during a single experimental period.

In our experiments, the oxygen content of the arterial blood increased in proportion to the increase in red cell concentration, whether the blood volume was maintained or reduced. This is also the case in human polycythemia vera (15). This finding is in contrast to the reduction in arterial oxygen saturation found after progressive plasmapheresis (13). We suggest that this inadequate oxygenation was due to the general anesthesia, which progressively deepened as plasmapheresis continued, and which, by affecting respiratory exchange, may have influenced oxygenation.

The only obvious mechanism available to the organism for restoring a normal total peripheral resistance $(T P R)$ when the blood viscosity has been raised is by reducing $R$, i.e., by increasing the capacity of the vascular bed. But vasoconstriction begins early in shock and persists in response to reduction in blood volume. Consequently, the animal in shock is vulnerable to the effects of an abnormal increase in blood viscosity. Cardiac output falls because of a rise in both components of $T P R$. Even if $R$ were able to drop as $\eta$ rose in animals with reduced blood volume, a fall in blood pressure would probably occur, but with little if any resulting benefit. These observations are of some interest to those concerned with the therapeutic possibilities in shock of sympathectomy and other vasodilating agents. It has been suggested (17) that vasoconstriction in shock may give way to vasodilation because of local chemical influences. We did not observe such an effect in these experiments on increased blood viscosity. However, when shock progresses to the "irreversible" phase, an increase in the capacity of the vascular bed occurs, as is evident from the observation that a progressively increasing blood volume is required to maintain a given blood pressure (18). Whether this increasing capacity is due to active vasodilation or is a passive response in toneless vessels is not clear.

While some of the differences in the hemodynamic phenomena of hemorrhagic and tourniquet shock may be attributable to fever, infection, or tissue damage in the latter, the increase in blood viscosity in tourniquet shock accounts for at least some, if not all, of the striking disparities observed between these forms of shock.

The restoration of blood volume in tourniquet shock results in an improvement in cardiac output, whether or not the elevated blood viscosity is also reduced. Restoration of normal blood viscosity alone cannot restore the normal cardiac output unless the blood volume deficiency is small. This suggests that in the therapy of the various forms of shock associated with high hematocrit, the correction of blood volume deficiency is more important than the correction of viscosity. Replacement of lost plasma by red cells or whole blood has been recommended (19); i.e., that burns should be best treated by whole blood. This suggestion should be regarded with caution for unless the blood volume deficiency is adequately replaced and maintained, the rising blood viscosity produced by such therapy may exert a deleterious effect on cardiac output. When the blood viscosity is high, the arterial blood pressure level is a particularly misleading index of the overall blood flow, so that treatment guided by the blood pressure level may well lead to failure to provide sufficient blood volume replacement.

\section{SUMMARY AND CONCLUSIONS}

1. The constant $(K)$ in Poiseuille's equation (1) was determined in 23 normal dogs, assuming the peripheral resistance $(R)$ to be unity per kgm. 
of normal dog where

$$
R=\frac{\text { total peripheral resistance }(T P R)}{\text { viscosity }(\eta)}
$$

2. Using this constant $(K)$, the peripheral resistance $(R)$ of dogs subjected to various experimental procedures was calculated as a ratio to the peripheral resistance per $\mathrm{kgm}$. of normal dog and correlated with the cardiac output, apparent relative viscosity of blood, and mean blood pressure.

3. In normal unanesthetized dogs cardiac output per kgm. of dog and cardiac index were found to be larger and more variable than reported by others for anesthetized dogs.

4. The withdrawal and immediate return of the same volume of blood from one vein to another produces less disturbance of the hemodynamic equilibrium in normal dogs than a similar exchange between an artery and a vein.

5. When the hematocrit is raised by a venovenous exchange of packed red cells for whole blood, normal dogs with a normal blood volume can compensate for the rise in viscosity by lowering peripheral resistance $(R)$. They are able to maintain a constant total peripheral resistance, cardiac output, and blood pressure, providing $R$ has not been affected by increases in vasoconstriction due to extraneous factors.

6. When, in normal dogs with a normal blood volume, the hematocrit is raised by an arteriovenous exchange of packed red cells for whole blood, a fall in cardiac output and a rise in peripheral resistance results. The blood pressure of these dogs remains constant.

7. Increase in blood viscosity aggravates hemorrhagic shock by further reducing blood flow. The dog in hemorrhagic shock cannot compensate for the increase in blood viscosity by reduction in peripheral resistance $(R)$ if blood pressure is to be maintained.

8. When blood viscosity is made abnormally high, the cardiac output in hemorrhagic shock becomes critically low at blood pressures higher than those observed in hemorrhagic shock in which the blood viscosity is not altered. Blood pressures are high in relation to the fall in cardiac output throughout the course of shock in animals with high blood viscosity and these blood pressure levels may produce a deceptively favorable im- pression of the state of the circulation. Indeed such dogs become "irreversible" $(11,18)$ at relatively high blood pressures $(80 \mathrm{~mm}$. $\mathrm{Hg}$ and higher). The cardiovascular dynamics and general appearance of dogs in hemorrhagic shock, whose hematocrits have been experimentally elevated, resemble those of dogs in tourniquet shock.

9. In hemorrhagic shock in which abnormally high blood viscosity is produced, the restoration of the original blood viscosity partially restores the normal cardiac output, but the reduction of viscosity to lower than original levels increases cardiac output further. In experiments in which hemorrhage of 18 to $22 \mathrm{ml}$. per $\mathrm{kgm}$. was performed, and the hematocrit was raised to 65 to 75 per cent, the restoration of cardiac output by return of blood viscosity to the original level was estimated to be 10 to 50 per cent of the total drop in cardiac output produced by the rise in hematocrit and by the hemorrhage.

10. The percentage of drop in cardiac output with increase in viscosity is much greater at reduced blood volume than when the blood volume is normal.

11. The sharp drop in cardiac output observed shortly after removal of tourniquets and while the blood pressure is still above ordinary shock levels is due both to fall in blood volume and to increase in blood viscosity. "Irreversibility" in tourniquet shock develops at higher blood pressure levels than in hemorrhagic shock because of the lowered cardiac output, which we attribute to the increased hematocrit in the former.

12. Restoration of the original circulating blood volume in tourniquet shock without correction of hematocrit does more to restore cardiac output than does restoration of the original blood viscosity. In late tourniquet shock, these responses may not occur.

13. Restoration of normal cardiac output of dogs in tourniquet shock can be achieved by reducing the hematocrit to low levels (10 to 20 per cent). Nevertheless, recovery from shock will not result unless blood volume is also restored.

14. It is concluded that if an abnormally high viscosity exists in shock and is not treated effectively, the restoration and maintenance of normal blood volume becomes all the more urgent.

Acknowledgment is due Miss Martha Goldberg and Mrs. Shiffre Shactman for technical assistance. 


\section{BIBLIOGRAPHY}

1. Fine, J., Frank, H. A., and Seligman, A. M., Traumatic shock. VIII. Studies in the therapy and hemodynamics of tourniquet shock. J. Clin. Invest., 1944, 23, 731.

2. Cannon, W. B., Traumatic Shock. D. Appleton \& Co., New York, 1923.

3. Green, H. N., Shock producing factors from striated muscle; isolation and biological properties. Lancet, 1943, 2, 147.

4. Aub, J. C., A toxic factor in experimental traumatic shock. New Eng. J. Med, 1944, 231, 71.

5. Whittaker, S. R. F., and Winton, F. R., The apparent viscosity of blood flowing in the isolated hind limb of the dog, and its variation with corpuscular concentration. J. Physiol, 1933, 78, 339.

6. Green, H. D., Lewis, R. N., Nickerson, N. D., and Heller, A. L., Blood flow, peripheral resistance and vascular tonus with observations on the relationship between blood flow and cutaneous temperature. Am. J. Physiol., 1944, 141, 518.

7. Wiggers, H. C., Cardiac output and total peripheral resistance measurements in experimental dogs. Am. J. Physiol., 1944, 140, 519.

8. Pappenheimer, J. R., and Maes, J. P., Quantitative measure of vasomotor tone in hindlimb muscles of dog. Am. J. Physiol., 1942, 137, 187.

9. Van Slyke, D. D., and Neill, J. M., The determination of gases in blood and other solutions by vacuum extraction and manometric measurement. J. Biol. Chem., 1924, 61, 523.

10. Benedict, F. G., Surface-area constant in comparative physiology. Yale J. Biol. and Med., 1932, 4, 385.
11. Frank, H. A., Seligman, A. M., and Fine, J., Traumatic shock. $X$. The treatment of hemorrhagic shock irreversible to replacement of blood volume deficiency. J. Clin. Invest., 1945, 24, 435.

12. Page, I. H., The occurrence of a vasoconstrictor substance in blood during shock induced by trauma, hemorrhage and burns. Am. J. Physiol., 1943, 139, 386.

13. Price, P. B., Metcalf, W., Longmire, W. P., Hanlon, C. R., and Rizzoli, H. V., Experimental shock. II. Effects of acute plasmapheresis in healthy dogs. Bull. Johns Hopkins Hosp., 1944, 75, 14.

14. Green, H. D., Dworkin, R. M., Antos, R. J., and Bergeron, G. A., Ischemic compression shock, with an analysis of local fluid loss. Am. J. Physiol., 1944, 142, 494.

15. Altschule, M. D., Volk, M. C., and Henstall, H., Cardiac and respiratory function in polycythemia vera. Am. J. Med. Sci., 1940, 4, 478.

16. Wood, G. D., and Blalock, A., Effects of uncomplicated hemoconcentration (erythrocytosis). Arch. Surg., 1941, 42, 1019.

17. Wiggers, H. C., and Middleton, S., Cardiac output and total peripheral resistance in post-hemorrhagic hypotension and shock. Am. J. Physiol., 1944, 140, 677.

18. Frank, H. A., Seligman, A. M., and Fine, J. Traumatic shock. XIII. The prevention of irreversibility in hemorrhagic shock by vivi-perfusion of the liver. J. Clin. Invest., 1946, 25, 22.

19. Moyer, C. A., Coller, F. A., Job, V., Vaugham, H. H., and Marty, D. A study of the interrelationship of salt solutions, serum and defibrinated blood in the treatment of seventy scalded, anesthetized dogs. Ann. Surg., 1944, 120, 367. 